\title{
Meliola Marthomaensis Sp. Nov. an Addition to Meliolaceae from Western Ghat Region in Kerala State, India
}

\author{
Jacob Thomas", Teena Elizabeth Alex, Riya J. Thomas \\ PG \& Research Dept. of Botany, Mar Thoma College, Thiruvalla 689103, Kerala, India \\ *Corresponding Author:jacobnthomas@gmail.com
}

Copyright (C) 2013 Horizon Research Publishing All rights reserved

\begin{abstract}
During the exploration of foliicolous fungi in the Pathanamthitta district of Western Ghats region of Kerala state, Hymenodictyon obovatum Wallich. (Rubiaceae) was found infected with black mildew fungus. Critical microscopic examination of the fungus revealed that it is hitherto undescribed species of the genus Meliola Fr. and hence the report.
\end{abstract}

Keywords Meliola, New species, Western Ghats, Kerala, India

\section{Introduction}

Black Mildews are the group of black colony forming parasitic fungi belong to several taxonomic groups, namely Hyphomycetes, Meliolales, Schiffnerula and its anamorphic forms, Majority of the black mildews are obligate biotrophs but a few are necrotrophs and host specific with a very narrow host range. Hence, identity of the host plant, preferably up to species level, needs to be known for the correct identification of these fungi. Among the black mildews, meliolaceous fungi are the obligate parasites, predominantly ectophytic, host specific, usually infect leaves, petioles, young and soft stems, produce superficial mycelium, which in turn produces both appressoria and phialides. Mycelial setae borne from the hyphae are produced laterally and immediately they take a perpendicular position. Perithecia are flattened globose to globose, non-ostiolate to ostiolate, the outer wall of the perithecia is dark and thick, while, the inner wall is thin and hyaline. Perithecia supplemented with appendages, conoid cells and setae. Asci many, arranged on the basal hymenium, mostly clavate to cylindrical, 2-8 spored and evanescent. Ascospore 1-4 septate, initially hyaline but brown at maturity.

During a survey of the foliicolous fungi in the Western Ghats region of Kerala state, several foliicolous fungi have been collected from Thiruvalla, Pthanamthitta district. Of these, Meliola marthomaensis sp. nov. is described and illustrated in detail.

\section{Materials and Methods}

Infected plant parts were noticed carefully in the field, field notes made regarding their pathogenicity, nature of colonies, nature of infection, locality, altitude, etc. In the field, each infected plants were collected separately in polythene bags. These infected plant parts were pressed neatly and dried in-between blotting papers. After ensuring their dryness, they were kept in the manifold or butter paper folders. For microscopic study, scrapes were taken directly from the infected host and mounted in $10 \% \mathrm{KOH}$ solution. After 30 minutes, KOH was replaced by Lacto phenol, prepared according to Rangaswamy, 1975, [1].

Nail polish technique of Hosagoudar and Kapoor, 1985 [2] used to study the entire colony in its natural condition. A drop of high quality well transparent nail polish were applied to the selected colonies and carefully thinned with the help of a fine brush without disturbing the colonies. Colonies with hyperparasites show wooly nature and were avoided. When the nail polish on the colonies dried fully, a thin, colourless film or flip formed with the colonies firmly embedded in it. A drop of DPX will be spread on a clear slide and the flip were spread properly on it. One or two more drops of DPX again added on the flip and a clean cover glass were placed over it and a gentle pressure on the cover glass brings out the excess DPX and it will be removed after drying. These slides were labeled and placed in a dust free chamber for 1-2 days for drying. These permanent slides were then used for further studies. Microscopic studies were carried with the help of Primus (PMD117-M) Compond microscope with Scopeimage-9 image analyzer software and microphotographs were taken by inbuilt CMOS camera of 1.3 megapixels. After the study of each collection, the materials were deposited in the Mar Thoma College Travancore Herbarium (MTCTH), Kerala, India. 


\section{Results}

\section{TAXONOMY}

Meliola marthomaensis sp. nov. Jacob Thomas, Teena Elizabth Alex and Riya J. Thomas (Fig. 1) (Plate-1)
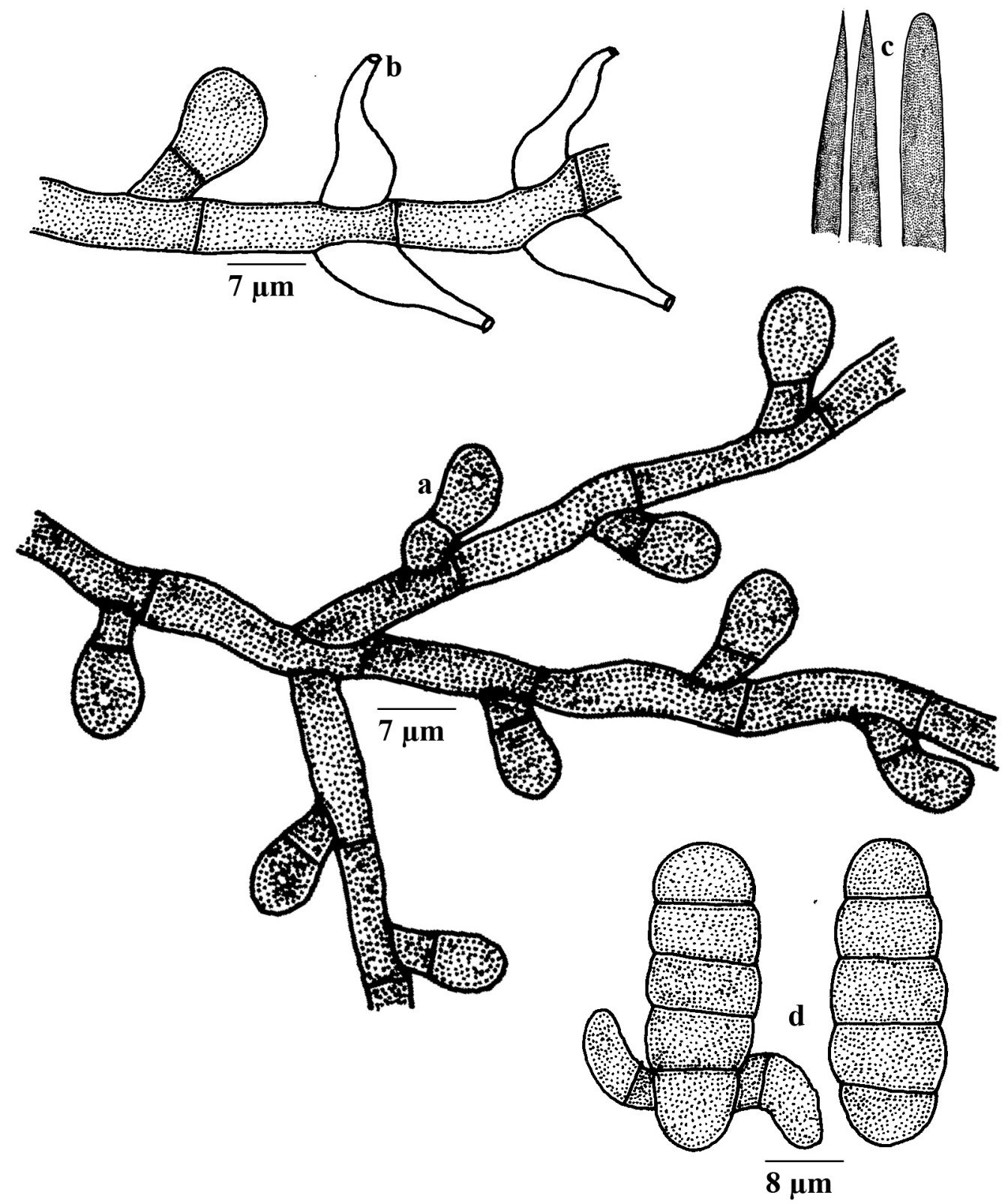

a. Appressoria, b. Phialide, c. Apical portion of mycelial setae, d. Ascospores Figure 1. Meliola marthomaensis sp. nov. 

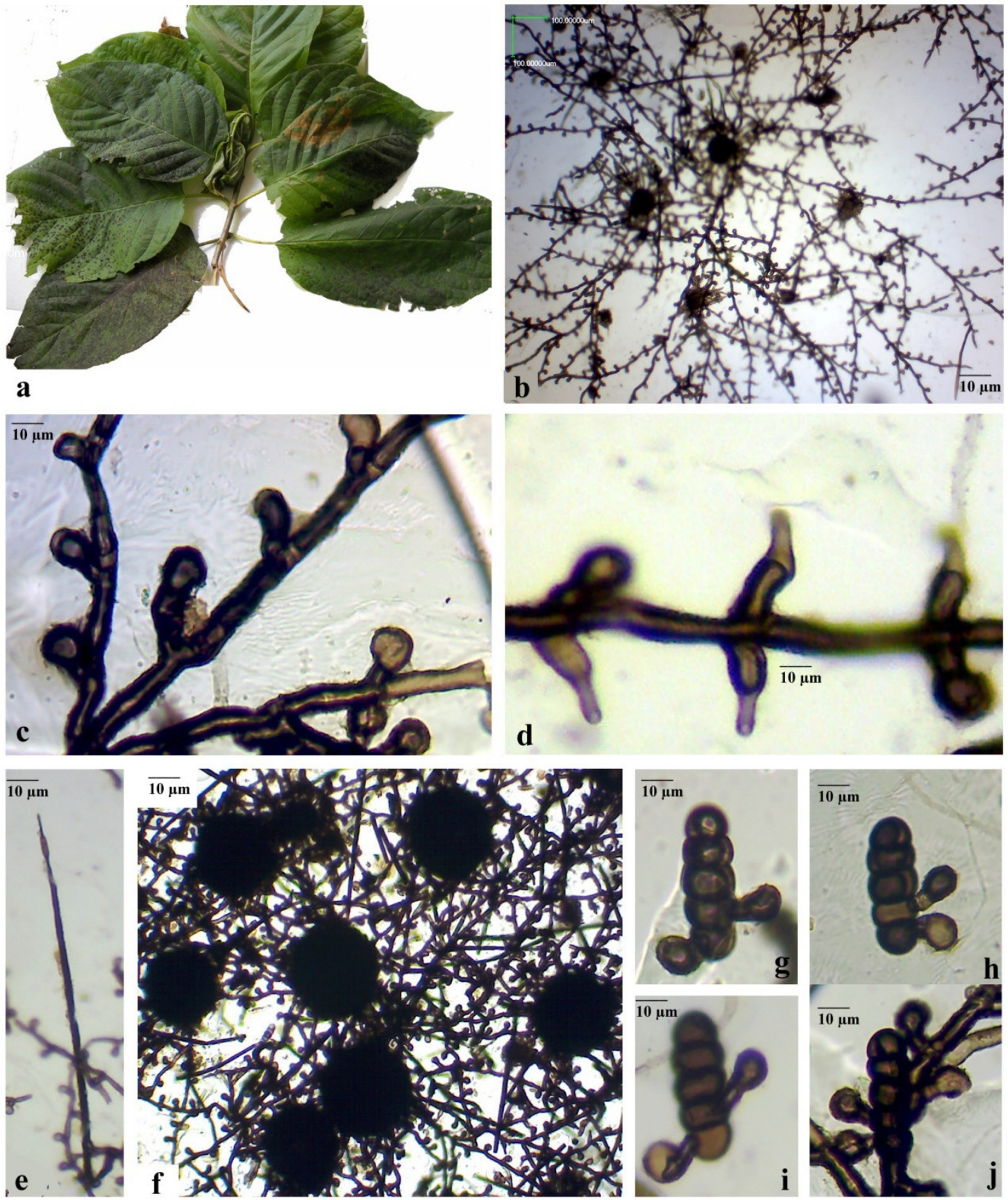

Plate-1: Meliola marthomaensis sp. nov.

a. Infected leaves of Hymenodictyon obovatum Wallich., b. Colony with perithecia,

c. Appressoriate mycelium, d. Phialides, e. Mycelial seta, g-j. germinating ascospores 
Coloniae plerumque epiphyllae, raro amphigenae, densae, velutinae, ad $5 \mathrm{~mm}$ in diam., confluentes. Hyphae rectae vel undatus, opposite acuteque ramosae, laxe vel arte reticulatae, cellulae $19-48 \times 4-5 \mu \mathrm{m}$. Appressoria alternata, recta vel leniter curvula, antrorsa, 11-18 $\mu \mathrm{m}$ longae; cellulae basilares cylindraceae vel cuneatae, 3-6 $\mu \mathrm{m}$ longae; cellulae apicales subgloboae vel ovatae, integrae, ad apicem rotundatae, 8-12 $\mathrm{x} 7-11 \mu \mathrm{m}$. Phialides appressoriis intermixtae, alternatae vel oppositae, ampulliformes, 13-25 x 5-7 $\mu \mathrm{m}$. Setae myceliales dispersae, simplices, rectae, acutae vel obtusae ad apicem, ad $500 \mu \mathrm{m}$ longae. Perithecia dispersa, verrucosa, ad $150 \mu \mathrm{m}$ diam.; ascosporae cylindraceae, 4-septatae, constrictae ad septatae, $42 \times 44-14-16 \mu \mathrm{m}$.

Colonies mostly epiphyllous rarely amphigenous, dense, velvety upto $5 \mathrm{~mm}$ diameter, Hyphae straight to undulate, branching opposite acute angles, loosely to closely reticulate cell $19-48 \times 4-5 \mu \mathrm{m}$. Appressoria alternate, straight to slightly curved, antrorse, $11-18 \mu \mathrm{m}$ long, stalk cells cylindrical to cuneate $3-6 \mu \mathrm{m}$ long, head cells subglobose to ovate, entire, rounded at the apex, 8-12 $\times 7-11 \mu \mathrm{m}$. Phialides mixed with appressoria, opposite to alternate, ampulliforms, 13-25 x $5-7 \mu \mathrm{m}$. Mycelial setae scattered, simple, straight, acute to obtuse at the tip, up to $500 \mu \mathrm{m}$ in length. Perithecia scattered, verrucose, upto $150 \mu \mathrm{m}$ in diam., ascospores cylindrical, 4 -septate constricted at the septa $42 \times 44-14-16 \mu \mathrm{m}$.

Material examined: On the leaves of Hymenodictyon obovatum Wallich. (Rubiaceae), Nedumpuram, Pathanamthitta, Kerala, July 15, 2012, Teena Elizabeth Alex, MTCTH 101 (Holotype), MTCH 102 (Isotype), MB 803893 (Mycobank).

\section{Discussion}

The name of the host is as treated by Nayar et al., 2006 [3]. Based on the Beeli formula 3113.3222, this species can be compared with Meliola rechingeri Hansf. known on Psychotria sp. from Samoa, reported by Hansford in 1961 [4]. However, differs from it in having longer appressoria, ovate to globose head cells of appressoria, longer mycelia setae and larger ascospores. It also can be compared with Meliola cadambae Hosag. \& C.K. Biju known on Neolamarkia cadamba (Roxb.) Bosser, reported by Hosagoudar in 2008 [5] which bearing both alternate and opposite appressoria whereas the new species reported here having only alternate appressoria.

Meliolaceous fungi are predominantly foliicolous and rarely infect the soft stems and tender shoots. Members of Meliolales are generally shade and moisture loving, prefer $19-25^{\circ} \mathrm{C}$ temperature, $50-65 \%$ relative humidity, $40-200 \mathrm{~mm}$ rainfall and an altitude of 100-1868 m. Hence, they occur luxuriantly in the present study area. Here the $M$. marthomaensis infected whole leaves of the host plant except tender leaves. However, the present species not producing any pathogenic effects, but it may reduce the photosynthetic efficiency and aesthetic beauty of the host plant.

\section{Acknowledgements}

We thank are due to Prof. Kurian John, Mar Thoma College, Thiruvalla for providing facilities and UGC, Govt. of India, New Delhi for financial support to conduct the research.

\section{Conflict of Interests}

The authors declare that they do not have any conflict of interests.

\section{REFERENCES}

[1] Rangaswamy, G. (1975). Diseases of Crop plants in India. Prentice - Hall of India, Pvt. Ltd., New Delhi.

[2] Hosagoudar, V. B. and J. N. Kapoor (1985). New technique of mounting meliolaceous fungi. Indian Phytopathol. 38: 548-549.

[3] Nayar, T.S., Beegum Rasiya, A., Mohanan, N. and Rajkumar, G., (2006). Flowering Plant of Kerala-A Handbook, p518.

[4] Hansford, C.G. (1961). The Meliolaceae. A Monograph. Sydowia. Beih. 2: 1-806.

[5] Hosagoudar, V. B. (2008). Meliolales of India, vol. II. Botanical Survey of India, Calcutta, Pp 197-200 